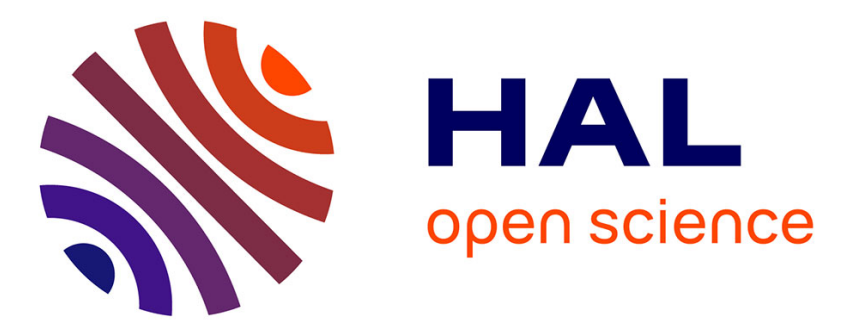

\title{
Electrostatic interactions favor the binding of positive nanoparticles on cells: a reductive theory
}

\author{
Valérie Forest, Michèle Cottier, Jérémie Pourchez
}

\section{To cite this version:}

Valérie Forest, Michèle Cottier, Jérémie Pourchez. Electrostatic interactions favor the binding of positive nanoparticles on cells: a reductive theory. Nano Today, 2015, 10 (6), pp.677-680. 10.1016/j.nantod.2015.07.002 . hal-01891015

\section{HAL Id: hal-01891015 \\ https://hal.science/hal-01891015}

Submitted on 9 Oct 2018

HAL is a multi-disciplinary open access archive for the deposit and dissemination of scientific research documents, whether they are published or not. The documents may come from teaching and research institutions in France or abroad, or from public or private research centers.
L'archive ouverte pluridisciplinaire HAL, est destinée au dépôt et à la diffusion de documents scientifiques de niveau recherche, publiés ou non, émanant des établissements d'enseignement et de recherche français ou étrangers, des laboratoires publics ou privés. 
Electrostatic interactions favor the binding of positive nanoparticles on cells: a reductive theory

Valérie Forest*a, Michèle Cottierb,c, Jérémie Pourcheza.

a École Nationale Supérieure des Mines de Saint-Etienne, CIS-EMSE, LINA EA4624, SFR IFRESIS, F-42023 Saint-Etienne, France.

b Université Jean Monnet, LINA EA4624, SFR IFRESIS, F-42023 Saint-Etienne, France.

c CHU de Saint-Etienne, F-42055 Saint-Etienne, France.

* Corresponding author: Valérie Forest:

École Nationale Supérieure des Mines de Saint-Etienne

158 cours Fauriel

CS 62362

42023 Saint-Etienne Cedex 2

FRANCE

Email address: vforest@emse.fr - Telephone number: +33477499776 


\section{Graphical abstract}

Positively charged nanoparticle

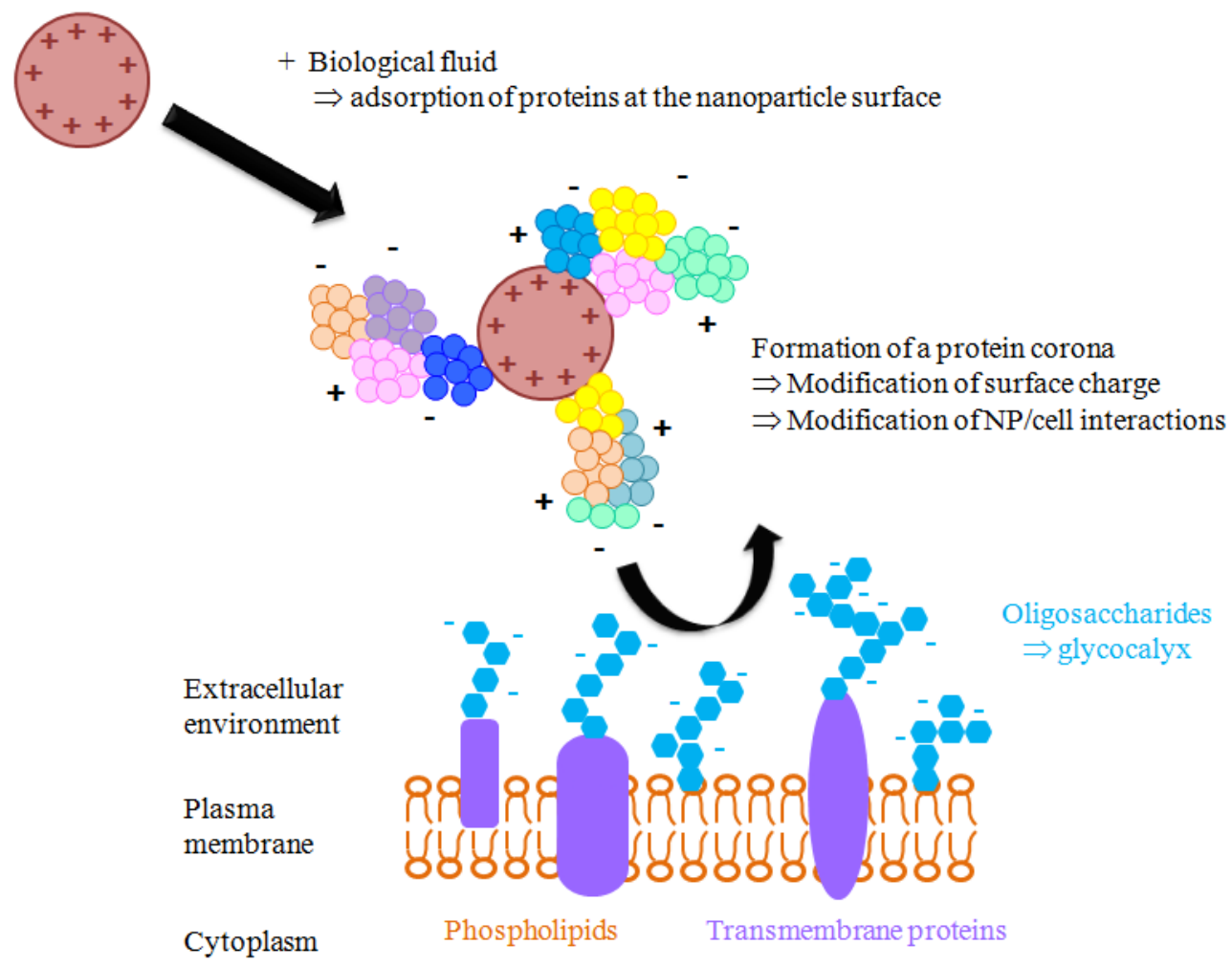

\section{$\underline{\text { Highlights }}$}

- Positive nanoparticle/cell membrane interactions are privileged.

- It is supposedly due to favorable electrostatic interactions.

- But in biological media, a protein corona forms and adds a level of complexity. 


\section{$\underline{\text { Abstract }}$}

It is acknowledged that physico-chemical features of nanoparticles have a major impact on their uptake, and especially their surface charge. A widespread observation is that positively charged nanoparticles are more uptaken by cells than neutral or negatively charged nanoparticles. The reason commonly evoked is the favorable electrostatic interactions with negatively charged cell membrane. However, this explanation seems simplistic as it does not take into account a fundamental element: the nanoparticle protein corona. This adds a new level of complexity in the interactions with biological systems that cannot be any more limited to electrostatic binding.

\section{$\underline{\text { Key-words }}$}

Nanoparticle, Protein corona, Nanoparticle/cell interactions, Cellular uptake. 


\section{Introduction}

The investigation of nanoparticle/cell interactions is a crucial issue with regard to two fields: nanomedicine and nanotoxicology. First, nanoparticles can be used as therapeutic and/or diagnostic agents for biomedical applications. These latter usually have intracellular targets, therefore the nanodevice must be able to enter the cell to reach its objective and exert its effects [1]. Second, one major concern with nanoparticles lies in their size, high reactivity and large surface area that allow them to interact with cell components, to interfere with the cell machinery, potentially triggering side effects and toxicity. Accordingly, understanding the underlying mechanism of cellular uptake is an important step towards understanding the biological fate of nanoparticles, both the favorable and adverse aspects [1]. It is commonly admitted that nanoparticles physico-chemical features are determining factors in nanoparticle/cell interactions and consequently influence cell behavior. In addition to parameters such as size and shape, chemical functionalities on the surface seem to play a critical role in binding to cell membrane and subsequent cellular uptake [2,3]. More specifically, surface charge is a crucial parameter but as many concepts could be hidden behind the term of charge depending on the level of observation (macro- or micro-scale) it requires brief definitions.

\section{A brief definition of nanoparticle charge and cell membrane charge}

Regarding nanoparticles, the term charge is confusing as it could refer to distinct and complex physical quantities. The nanoparticle surface charge is initially characterized by its surface potential, but as soon as the nanoparticle is exposed to a fluid a double electrical layer appears on its surface, consisting in two parallel layers of charges surrounding the nanoparticle. The first layer, called the Stern layer, corresponds to the primary electric surface potential or Stern potential (caused by protonation/deprotonation reactions on the surface) and ions from the bulk electrolyte strongly bound to its surface. The second diffuse outer layer is composed of free ions attracted to the primary electric surface potential of the particle. The external potential, called the zeta potential, is widely used in the literature for the quantification of the nanoparticle charge. However, it is rigorously not equal to the electric surface potential nor to the Stern potential because these are defined at different locations in the electrical double layer [4].

Regarding cell membrane, surface charge and membrane potential are often confused and a sharper distinction should be done between the two as they refer to different concepts. Membrane potential is due to ion distribution between both sides of the membrane following 
the Nernst principle. Surface charge corresponds to the distribution of charges in a surface: typically, cell surface is covered by a carbohydrate coat, known as the glycocalyx, bearing negative charges. This is why cell membrane is generally considered as globally negatively charged [5].

\section{Cellular uptake of nanoparticles depending on nanoparticle surface charge}

The uptake of nanoparticles by cells can be viewed as a two-step process: binding to the cell membrane and internalization. The first one seems to be most affected by the physicochemical characteristics of the particles and especially the surface charge [6,7]. It is commonly acknowledged that positively charged nanoparticles are more internalized by cells than neutral or negatively charged nanoparticles $[1,2,6,8-14]$. The accepted explanation lies in the fact that electrostatic interactions are favored with cell membrane that is negatively charged. This observation seems to be a general tendency, observed with nanoparticles of various chemical bulk compositions (silica, gold, iron oxide...), in various cell types and with different types of functionalization $[8,15,16]$. This is why positively charged nanoparticles are usually chosen as carriers for drug or gene delivery $[1,2,14]$.

However, there has been evidence of cellular uptake of negatively charged particles $[2,10]$, suggesting that electrostatic interactions only partly contribute to nanoparticle/cell interaction. Consequently, the widespread theory that the preferential cellular uptake of positively charged nanoparticles over neutral or negatively charged nanoparticles is due to favorable electrostatic interactions with cell membrane seems simplistic and reductive. Indeed, it only considers the nanoparticle charge (i.e. the surface potential) whereas many other parameters are involved in the equation. For instance, it does not take into account a fundamental element which importance is increasingly documented: the protein corona.

\section{The key role of the protein corona}

Once introduced in a biological milieu nanoparticles are surrounded by a wide variety of biomolecules which rapidly adsorb at the surface and entirely cover the nanomaterial. This so-called protein corona modifies the original nanoparticle physico-chemical features and generates a new interface defining the "biological identity" of the nanoparticle. This change adds an additional level of complexity for the biological responses [3,9,12,17-21]. The formation of the protein corona is a dynamic process consisting in the competitive binding of biomolecules at the nanoparticle surface. The most abundant proteins in the medium first adsorb, but over time they are replaced by proteins of higher affinity due to a Vroman's 
effect $[3,18,19,22]$. Similarly, the protein corona composition varies depending on the nanoparticle environment (as they can travel through various compartments) $[3,17,18,23]$. The formation of the protein corona depends on the physico-chemical properties of the nanomaterial (especially surface charge, hydrophobicity, size, but also shape, composition, surface functional groups...), on the nature of the physiological environment (blood, interstitial fluid, cytoplasm, organelles...), and on the duration of exposure [18-20,23].

Although difficult to characterize precisely because of its complex and dynamic nature, the existence of this protein corona is beyond doubt and it is recognized that its formation induces changes in the hydrodynamic diameter and zeta potential of the nanoparticle $[17,19,21,24]$. When nanoparticles are incubated with serum such a change can occur that initially positively charged nanoparticles can turn negative [19,22,25-29]. Therefore, the presence of a protein corona can significantly modify the surface properties of a nanoparticle (and especially their electrical surface potential) sometimes masking the expected effects of purposely grafted molecules [20]. The resulting new nanoparticle interface may play an important role in its interactions with cell surfaces as it is what cells "see" and can deeply affect the biological responses, nanoparticle biodistribution and generally nanoparticle fate $[1,7,12,17,18,23,24,30-32]$.

Although a clear correlation was established between the nanoparticle corona and cellular uptake, discrepancies are reported in the literature some studies showing that protein adsorption on nanoparticle decreases their cellular internalization [20,21,23,31,32] while other tend to demonstrate the opposite $[22,28,29]$. An explanation could be that nanoparticles with more proteins on surface may have a higher possibility to expose ligands which can recognize the membrane receptors and facilitate the transmembrane internalization [1,29]. Therefore conflicting results may be related to different endocytosis pathways.

For all these reasons it seems improper to propose, as mentioned before the widespread theory of "the positively charged nanoparticles interact more with cells than negatively charged nanoparticles due to the negative charge of cell membrane". Even if it is true that the initial charge of the nanoparticle actually influences the nature of the proteins that adsorb and consequently has an indirect impact on nanoparticle/cell interactions.

\section{$\underline{\text { Future directions }}$}

It is quite challenging to draw firm conclusions from studies dealing with nanomaterials interacting with living systems as many conflicting data are reported in the literature. A hurdle to the comparison of results from different groups may partly lie in the fact that some 
parameters are not defined precisely. For example, speaking of the nanoparticle charge, interpretations could be different if one considers the nanoparticle surface potential, the Stern potential or the zeta potential. We think it is mandatory to characterize as well as possible each parameter involved in the system. Similarly, if nanoparticles usually undergo a thorough physico-chemical characterization after their synthesis to get their initial features, these parameters are not always assessed in a biological context (i.e. in the biological medium where subsequent assays will be carried out). This crucial step should be done systematically as the nanoparticle "identity" would undoubtedly be altered after contact with a biological environment. Finally, to really take into account the complexity of the events it should be sometimes necessary to develop new tools or better adapted protocols.

\section{Conclusion}

Nanoparticle/cell interactions depend on many parameters. Among them protein corona has a major influence. Especially regarding the recognized privileged interaction of positively charged nanoparticles with cell membrane it is clear that with adsorbed proteins, the picture is more complicated than opposite surface charges mediating electrostatic interactions. The charge of the protein coat rather than the native particle surface will determine electrostatic binding [22]. As the biological consequences of a nanoparticle/cell interaction cannot be fully evaluated in the absence of the context, i.e. without taking into account the biological environment, we highly recommend considering the combined contribution of the physicochemical properties and the dynamic protein corona $[3,19]$. A better understanding of this relationship is a crucial issue both in terms of biomedical applications and nanosafety issues.

\section{$\underline{\text { Acknowledgements }}$}

The authors would like to acknowledge the French Ministry of the Economy, Finance and Industry, the Région Rhône-Alpes and the Conseil Général de la Loire for the financial support. 


\section{$\underline{\text { References }}$}

[1] F. Zhao, Y. Zhao, Y. Liu, X. Chang, C. Chen, Y. Zhao, Small Weinh. Bergstr. Ger. 7 (2011) 1322.

[2] A. Verma, F. Stellacci, Small Weinh. Bergstr. Ger. 6 (2010) 12.

[3] L. Shang, K. Nienhaus, G.U. Nienhaus, J. Nanobiotechnology 12 (2014) 5.

[4] M. Barisik, S. Atalay, A. Beskok, S. Qian, J. Phys. Chem. C 118 (2014) 1836.

[5] Alberts, Bruce, Johnson, Alexander, Lewis, Julian, Raff, Martin, Roberts, Keith, Walter, Peter, in:, Mol. Biol. Cell, 5th ed., 2007.

[6] S. Patil, A. Sandberg, E. Heckert, W. Self, S. Seal, Biomaterials 28 (2007) 4600.

[7] N. Oh, J.-H. Park, Int. J. Nanomedicine 9 Suppl 1 (2014) 51.

[8] S. Kralj, M. Rojnik, R. Romih, M. Jagodič, J. Kos, D. Makovec, J. Nanoparticle Res. 14 (2012) 1.

[9] A. Panariti, G. Miserocchi, I. Rivolta, Nanotechnol. Sci. Appl. 5 (2012) 87.

[10] C. Schweiger, R. Hartmann, F. Zhang, W.J. Parak, T.H. Kissel, P. Rivera_Gil, J. Nanobiotechnology 10 (2012) 1.

[11] C. He, Y. Hu, L. Yin, C. Tang, C. Yin, Biomaterials 31 (2010) 3657.

[12] M. Nazarenus, Q. Zhang, M.G. Soliman, P. Del Pino, B. Pelaz, S. Carregal-Romero, J. Rejman, B. Rothen-Rutishauser, M.J.D. Clift, R. Zellner, G.U. Nienhaus, J.B. Delehanty, I.L. Medintz, W.J. Parak, Beilstein J. Nanotechnol. 5 (2014) 1477.

[13] S.-H. Yang, D. Heo, J. Park, S. Na, J.-S. Suh, S. Haam, S.W. Park, Y.-M. Huh, J. Yang, Nanotechnology 23 (2012) 505702.

[14] Z.-G. Yue, W. Wei, P.-P. Lv, H. Yue, L.-Y. Wang, Z.-G. Su, G.-H. Ma, Biomacromolecules 12 (2011) 2440.

[15] A. Lankoff, M. Arabski, A. Wegierek-Ciuk, M. Kruszewski, H. Lisowska, A. BanasikNowak, K. Rozga-Wijas, M. Wojewodzka, S. Slomkowski, Nanotoxicology 7 (2013) 235.

[16] Y. Ge, Y. Zhang, J. Xia, M. Ma, S. He, F. Nie, N. Gu, Colloids Surf. B Biointerfaces 73 (2009) 294.

[17] I. Lynch, K.A. Dawson, Nano Today 3 (2008) 40.

[18] E. Izak-Nau, M. Voetz, S. Eiden, A. Duschl, V.F. Puntes, Part. Fibre Toxicol. 10 (2013) 56.

[19] N.P. Mortensen, G.B. Hurst, W. Wang, C.M. Foster, P.D. Nallathamby, S.T. Retterer, Nanoscale 5 (2013) 6372.

[20] E. Brun, C. Sicard-Roselli, Cancer Nanotechnol. 5 (2014) 7.

[21] D. Docter, C. Bantz, D. Westmeier, H.J. Galla, Q. Wang, J.C. Kirkpatrick, P. Nielsen, M. Maskos, R.H. Stauber, Beilstein J. Nanotechnol. 5 (2014) 1380. 
[22] M.S. Ehrenberg, A.E. Friedman, J.N. Finkelstein, G. Oberdörster, J.L. McGrath, Biomaterials 30 (2009) 603.

[23] S.R. Saptarshi, A. Duschl, A.L. Lopata, J. Nanobiotechnology 11 (2013) 26.

[24] Z.E. Allouni, N.R. Gjerdet, M.R. Cimpan, P.J. Høl, Int. J. Nanomedicine 10 (2015) 687.

[25] A. Kurtz-Chalot, J.P. Klein, J. Pourchez, D. Boudard, V. Bin, G.B. Alcantara, M. Martini, M. Cottier, V. Forest, J. Nanoparticle Res. 16 (2014) 1.

[26] M. Lundqvist, J. Stigler, G. Elia, I. Lynch, T. Cedervall, K.A. Dawson, Proc. Natl. Acad. Sci. U. S. A. 105 (2008) 14265.

[27] I.A. Pyshnaya, K.V. Razum, J.E. Poletaeva, D.V. Pyshnyi, M.A. Zenkova, E.I. Ryabchikova, BioMed Res. Int. 2014 (2014) 908175.

[28] Y. Qiu, Y. Liu, L. Wang, L. Xu, R. Bai, Y. Ji, X. Wu, Y. Zhao, Y. Li, C. Chen, Biomaterials 31 (2010) 7606.

[29] M.M. Yallapu, N. Chauhan, S.F. Othman, V. Khalilzad-Sharghi, M.C. Ebeling, S. Khan, M. Jaggi, S.C. Chauhan, Biomaterials 46 (2015) 1.

[30] P. Aggarwal, J.B. Hall, C.B. McLeland, M.A. Dobrovolskaia, S.E. McNeil, Adv. Drug Deliv. Rev. 61 (2009) 428.

[31] P.J. Smith, M. Giroud, H.L. Wiggins, F. Gower, J.A. Thorley, B. Stolpe, J. Mazzolini, R.J. Dyson, J.Z. Rappoport, Int. J. Nanomedicine 7 (2012) 2045.

[32] A. Lesniak, A. Campbell, M.P. Monopoli, I. Lynch, A. Salvati, K.A. Dawson, Biomaterials 31 (2010) 9511. 